\title{
The Political Cartel of Presidential Candidacy through Threshold Brings Up a Single Candidate
}

\author{
Muhammad Saad", Dian Fitri Sabrina*, Sukardi ${ }^{* *}$ \\ fm.saad0128@gmail.com \\ "Hasanuddin University \\ **Universitas Airlangga
}

Keywords:
Political Cartel;
President
Threshold; Single
Candidate.

\begin{abstract}
The practice of presidential nomination by using a threshold through political parties or coalitions of political parties in Indonesia is still carried out because Indonesia adheres to a multi-party system. However, the regulation regarding the threshold for presidential nomination is prone to political transactions between parties. The reason is that there is no equality of access to presidential nominations between new political parties and old political parties considering that political parties are a defining element of representative democracy (Political parties are a defining element of representative democracy), this practice threatens the rights of minority political parties and limits the emergence of presidential candidates. The threshold in the nomination of President based on the decision of the Constitutional Court of the Republic of Indonesia Number 74/PUU/XVII/2020 regarding the review of Law Number 7 of 2017 concerning Elections is referred to as an open legal policy which is the authority of the House of Representatives in forming the Law on Elections. This study aims to evaluate the application of the threshold in the nomination of President with the principle of justice. This research is a doctrinal research using a case approach and a law approach. This study was conducted by looking at the development of the application of thresholds in elections and the provisions stipulated in the Election Law. The results of the study indicate that it is necessary to establish an ideal implementation model based on the principle of justice in order to guarantee the rights of minority political parties and avoid the emergence of a single presidential candidate.
\end{abstract}

Copyright (C) 2022 Muhammad Saad, Dian Fitri Sabrina, Sukardi Published in Media Iuris. Published by Universitas Airlangga, Magister Ilmu Hukum.

\section{Introduction}

The regulation and prevention of high-cost politics has not been systematically constructed in the law, so that this problem becomes a latent problem in the administration of elections in Indonesia, systematic provisions seek to prevent money politics or transactional politics which at the high cost of politics in Indonesia have not been seen to be a concern legislator. The construction of political costs is very important to discuss considering that political parties are tools used in the general election process. 
Muhammad Saad, dkk: The Political Cartel of Presidential...

Elections are a democratic way to form and transfer power from the people to state authorities, as formulated by the International Commission of Jurist at its conference in Bangkok in 1965 that "Representation government is a government deriving its power and authority from the people which power and authority are exercised through representative freely choosen and responsible for them". ${ }^{1}$

Political construction greatly influences the general election model used in recruiting candidates proposed by political parties. The requirements for the nomination of President arise with the provisions of Article 7 of 2017 Law Number 7 of 2017 concerning Elections which regulates the presidential nomination threshold which requires the acquisition of seats of at least $20 \%$ (twenty percent) of the total number of DPR seats or a minimum of $25 \%$ (two percent). fifty five percent) of valid national votes in the previous election for DPR members. The President's threshold in its development uses the simultaneous General Election system, this is necessary to distinguish several variants of the threshold that is often used in the implementation of elections. The variants are the Electoral Threshold, Parliamentary Threshold, and Presidential Threshold.

In simple terms, the threshold is understood as the minimum limit of support or votes that must be owned to obtain certain rights in elections. In terms of functions and uses, the application of the threshold is to reduce the number of election participants, the number of political parties sitting in representative institutions, and the number of political parties in the nominations for president and vice president.

The birth of the presidential threshold forces political parties to form a party coalition so that the specified threshold can be met. Based on the results of the 20042019 elections, no political party has yet reached the specified threshold. The result of election 2004, only 7 political parties received votes exceeding the parliamentary threshold of $7 \%$ of the seats, namely: the GOLKAR Party, PDIP, PKS, PKB, PAN, PD, and PPP. Those who received more than $2 \%$ of the votes were PBB, PKPB,

${ }^{1}$ Janedri M Gaffar, Demokrasi dan Pemilu di Indonesia (Konstitusi Press 2013).[3]. 
PBR, and PDS. Although the threshold for the 2004 General Election has not been used, all political parties that gain seats, even if only one seat, remain part of the political parties in the DPR.

Table 1. Political Parties Contesting in the Election Meeting the 2009 Parliamentary Threshold

\begin{tabular}{|c|c|c|c|}
\hline Political Parties & voice & $\%$ & Seats \\
\hline Partai Demokrat (PD) & 21.703.137 & 20,85 & 148 \\
\hline $\begin{array}{l}\text { Partai Golongan Karya } \\
\text { (GOLKAR) }\end{array}$ & 15.037 .757 & 14,45 & 106 \\
\hline $\begin{array}{l}\text { Partai Demokrasi Indone- } \\
\text { sia Perjuangan (PDIP) }\end{array}$ & 14.600 .091 & 14,03 & 94 \\
\hline $\begin{array}{l}\text { Partai Keadilan Sejahtera } \\
\text { (PKS) }\end{array}$ & 8.206 .955 & 7,88 & 57 \\
\hline $\begin{array}{l}\text { Partai Amanat Nasional } \\
(\text { PAN) }\end{array}$ & 6.254 .580 & 6,01 & 46 \\
\hline $\begin{array}{l}\text { Partai Persatuan Pemban- } \\
\text { gunan (PPP) }\end{array}$ & 5.533 .214 & 5,32 & 38 \\
\hline $\begin{array}{l}\text { Partai Kebangkitan Bangsa } \\
(\mathrm{PKB})\end{array}$ & 5.146 .122 & 4,94 & 28 \\
\hline Partai Gerindra & 4.646 .406 & 4,46 & 26 \\
\hline Partai Hati Nurani Rakyat & 3.922 .870 & 3,77 & 17 \\
\hline $\begin{array}{l}\text { Partai Tidak Lolos Presi- } \\
\text { dential Threshold }\end{array}$ & 19.048 .653 & 18,29 & - \\
\hline Jumlah & 104.099 .785 & 100 & 560 \\
\hline
\end{tabular}

Sumber: KPU RI 2020.

Table 1 explains that in the 2009 election the parliamentary threshold was applied, the composition of the vote acquisition changed because political parties that did not reach the parliamentary threshold were not included in determining the distribution of seats in the DPR. Consequently, the number of political parties in the DPR has also decreased. Of the 38 political parties participating in the election, only 9 political parties met the parliamentary threshold. If the use of the parliamentary threshold in the 2009 election is associated with the voter turnout, there are around 19,048,653 votes spread across 29 political parties participating in the election that did not meet the threshold in parliament.

The number of votes almost reached that of the Democratic Party as the party that received the highest number of votes in the 2009 election. The parliamentary threshold actually had an impact on wasting voter votes given to parties that did 
Muhammad Saad, dkk: The Political Cartel of Presidential...

not meet the threshold. However, the goal of simplifying the number of political parties that fill seats in the DPR is fulfilled. When the threshold was re-applied in the 2014 election with a higher figure of $3.5 \%$, the number of political parties that fulfilled it increased by 10 political parties. Where there are 12 political parties participating in the general election and among them there are 10 political parties that meet the parliamentary threshold. Apart from the 9 political parties that already had seats in the previous DPR, the Nasdem Party as a new political party was able to meet this threshold. This means that referring to the 2014 election results, only 2 political parties did not meet the parliamentary threshold, namely PBB and PKPI. In the 2019 election, the number of participants again increased to 16 national political parties.

Based on the results of the recapitulation of the votes acquired by the political parties participating in the 2019 general election, only 9 political parties met the threshold of $4 \%$. The $4 \%$ threshold is regulated in PKPU Number 5 of 2019 concerning the determination of the threshold for obtaining valid votes nationally and the determination of political parties participating in the 2019 election. All political parties previously had seats in the DPR and managed to survive in the DPR, except for the Hanura Party, meanwhile of the 4 new parties, not one has met the $4 \%$ threshold. From Table 9 above, the total valid votes for political parties that meet the parliamentary threshold are 126,376,414 votes. Meanwhile, the total number of valid votes for political parties that did not meet the parliamentary threshold was $13,594,842$. This means that around $9.5 \%$ of the valid votes of political parties participating in the 2019 election cannot be converted into seats in the DPR. This further strengthens the view that the more political parties participating in the election, the more votes will be wasted or not represented by representative institutions, even though one of the principles of elections that must be respected is universal suffrage, which is actually not only the right to vote in elections. elections, but also includes the right to be represented in representative institutions. 


\section{Method}

The research method in this journal is normative legal research, using a legal approach, analyzing legal concepts and historical approaches. Analysis of the data using juridical interpretation and analyzed qualitatively, namely by describing, interpreting and systematically arranging logically according to the research objectives.

\section{Research Result and Analysist/Discussion}

\section{The Concept of Threshold}

According to Jimly Asshiddiqie, setting the threshold is a mechanism that must be used in a presidential system with multiple parties. The president needs majority support in parliament. Without absolute support, the President is very likely to be less decisive in his efforts to move the course of government and dayto-day development. With this Threshold system, in the long term it is hoped that it will ensure the simplification of the number of political parties in the future. The higher the threshold number, it is assumed that the faster the effort to achieve simplicity in the number of political parties. ${ }^{2}$

Threshold is English, which is translated into Indonesian can mean threshold. Meanwhile, in the Big Indonesian Dictionary $(\mathrm{KBBI}){ }^{3}$ the threshold is defined as the level of the limit that can still be accepted or tolerated. This threshold is adopted in the electoral system, as a formula for calculating votes and seats in a proportional representation system. Threshold can also be understood as a system of proportional representation, minimum numbers and proportions, of the number of voters to become representatives/delegates in parliament. Threshold term is also termed the minimum barrier. This term is often used to set the parliamentary threshold and the presidential threshold to be able to participate in elections. ${ }^{4}$

\footnotetext{
${ }^{2}$ Jimly Asshiddiqie, Memperkuat Sistem Pemerintahan Presidensiil (Universitas Negeri Jember, 14 November 2001) Pidato Ilmiah [3].

${ }^{3}$ Badan Pengembangan dan Pembinaan Bahasa, Kementerian Pendidikan, Kebudayaan, Riset, dan Teknologi Republik Indonesia "KBBI Daring" (2016) <https://kbbi.kemdikbud.go.id/ entri/AMBANG BATAS> diakses 28 September 2021.

${ }^{4}$ Matthew Justin Streb, Law and Elections Politics: The Rules of the Game (Routledge 2013).[1].
} 
Muhammad Saad, dkk: The Political Cartel of Presidential...

Andrew Reynolds explained that the effective threshold is a setting born of mathematical calculations in the General Election system. The effective threshold is also translated as a hidden threshold or natural threshold because the law does not explicitly state the minimum percentage of votes that must be met. The effective threshold places the size of the electoral district as an important mathematical aspect in determining seat acquisition. ${ }^{5}$

\section{Threshold strengthen presidential system}

The birth of a strong, stable, and effective presidential candidate to ensure the existence of a country requires a leader who is not only strong as President in the Executive Board but also has power in the legislative body in making decisions. Presidential candidates with a strong and effective state leadership model create a presidential system in which the President as head of state and at the same time head of government, with a presidential system can carry out his authority properly and overcome state problems in the administration of government. The presidential government system is interpreted clearly from the provisions of the constitution Article 4 paragraph (1) which states that the President of the Republic of Indonesia holds the power of government according to the Constitution. The legitimacy of the President as a government power is that the President is directly elected by the people and has a direct mandate by the people.

The direct presidential election process requires a standard of measurement as an indicator of the people's approval of the presidential and vice presidential candidate pairs, this standard can be realized through the percentage threshold of vote acquisition in the DPR in the legislative election. The use of this minimum percentage of seat acquisition is intended as an indicator of support from the DPR in the context of the check and balances function. It is hoped that this will provide a strong government system in which the DPR and the President can carry out

${ }^{5}$ Andrew Reynolds, et.al, Electoral System Design: The New InternationalIDEA Handbook (International IDEA 2015).[1]. 
their functions properly. ${ }^{6}$ In the Presidential Election Law, it is not regulated if there is only one candidate pair for president and vice president who registers with the General Election Commissions (KPU). ${ }^{7}$

\section{Party coalitions have an impact on the birth of a single candidate for President in the General Election}

The threshold for presidential nomination is carried out by a political party or a coalition of political parties. These conditions are regulated in Article 222 of Law Number 7 of 2017 concerning General Elections. coalition is a combination of political parties to collect thresholds in accordance with the conditions set by law. However, the super party coalition will give rise to a single candidate.

Seeing the results of the 2019 elections, the government of President Joko Widodo, which is supported by $82 \%$ of political parties in parliament or referred to as a super coalition, raises speculation about the emergence of a single candidate pair in the upcoming Presidential Election (2024). This can be seen from the total percentage of seats acquired by the two opposition parties, namely the Democratic Party and the Social Justice Party (PKS), which is only 18 percent. Provisions related to the emergence of a single candidate for the Presidential election were made possible due to the conditions that occurred and the support that only gathered on one political party in power (having the highest percentage of votes).

A single candidate in the Presidential election is possible if there is a strong push from the largest vote in parliament as a result of a party coalition, however, the party coalition that occurs in Indonesia is not the only alternative that can maintain relations between parties in the coalition continue to improve. The experience of the coalition during the SBY-JK administration in 2004-2009 was that several parties opposed the policies made by the President. this happens because the party coalition is not permanent and dynamic. In

${ }^{6}$ Rosa Ristawati, 'Pemilihan Umum Presiden dan Wakil Presiden Indonesia dalam Kerangka Sistem Pemerintahan Presidensiil' (2009) 2 Jurnal Konstitusi.[30].

7 Suharizal, 'Legalitas dan Implikasi Calon Tunggal pada Pemilu Presiden 2009' (2009) 2 Jurnal Konstitusi.[51]. 
Muhammad Saad, dkk: The Political Cartel of Presidential...

general, party coalitions are easy to share, especially when the general election is approaching, it is difficult to distinguish between supporting political parties and non-supporting political parties. ${ }^{8}$

\section{Political Cartel By Ruling Political Party}

Political cartels are usually created from coalitions between political elites. The elites of political parties join or form a coalition to minimize the losses that may be obtained in political practice. Political parties tend to choose coalitions with other political parties even though they have different ideologies or interests. The party opposition does not rule out the possibility of support for the government as a coalition party, for example during the SBY-JK administration where one of the opposition parties (the Golkar party) joined the government as well as in the post-election Jokowi-Ma'ruf administration re-coalition by involving rival parties other than the elected president in ministerial posts and strategic positions in nonministerial positions.

As it is known that the presidential threshold gives birth to a limited coalition of political parties. According to the presidential threshols symbol, it will give birth to pragmatic and transactional politics among political parties. This has resulted in the emergence of a gang coalition, which means that it is possible to create political parties that have difficulty finding a coalition that is unable to carry a presidential candidate because of the small number of seats and the threshold. ${ }^{9}$ This single candidate was born because of the high dowry from the party bearer. Then rationally, if there is a strong incumbent candidate, the candidate others will certainly calculate rationally. Instead of losing everything, it's better discouraged from becoming a candidate. Because they are just candidates had to pay the dowry. Not to mention the funds that will be used for campaigns, funds to win voters' votes, funds to secure votes starting from the TPS level to securing votes in the

\footnotetext{
${ }^{8}$ Saldi Isra, Sistem Pemerintahan Indonesia (Rajawali 2019).[216].

${ }^{9}$ Herlambang P Wiratraman, 'Pemilu dan Neo-Otoritarianisme', Prosiding Konferensi Hukum Tata Negara (2019).[101].
} 
KPU, Regency/Municipal KPU City, Provincial KPU, central KPU even up to the Constitutional Court level if this happens dispute. ${ }^{10}$

Table 2. The Strength of the Governing Party in the DPR 2004 Election Results and the Position of Ministers in the United Indonesia Cabinet (KIB) I SBY-JK ${ }^{11}$

\begin{tabular}{lcc}
\hline \multicolumn{1}{c}{ SUPPORTING PARTY } & $\begin{array}{c}\text { SEATS IN } \\
\text { DPR }\end{array}$ & $\begin{array}{c}\text { MINISTER IN } \\
\text { CABINET }\end{array}$ \\
\hline Golkar & 127 & 3 \\
PKB & 52 & 2 \\
PPP & 58 & 2 \\
PD & 56 & 2 \\
PKS & 45 & 3 \\
PAN & 53 & 3 \\
PBB & 11 & 1 \\
PKPI & 1 & 1 \\
Total & $\mathbf{4 0 4}$ & $\mathbf{1 7}$ \\
\hline
\end{tabular}

Table 3. The Strength of the Governing Party in the DPR 2009 Election Results and the Position of Ministers in the United Indonesia Cabinet (KIB) II SBY-Boediono ${ }^{12}$

\begin{tabular}{lcc}
\hline \multicolumn{1}{c}{ SUPPORTING PARTY } & $\begin{array}{c}\text { SEATS IN } \\
\text { DPR }\end{array}$ & $\begin{array}{c}\text { MINISTER IN } \\
\text { CABINET }\end{array}$ \\
\hline Partai Demokrat & 148 & 6 \\
Partai Golkar & 106 & 4 \\
\hline PKS & 57 & 4 \\
PAN & 46 & 3 \\
PPP & 38 & 2 \\
PKB & 28 & 2 \\
JUMLAH & $\mathbf{4 2 3}$ & $\mathbf{2 1}$ \\
\hline
\end{tabular}

${ }^{10}$ Iza Rumesten, 'Fenomena Calon Tunggal dalam Pesta Demokrasi' (2016) 13 Jurnal Konstitusi.[80].

${ }^{11}$ Lili Romli, 'Koalisi dan Konflik Internal Partai Politik pada Era Reformasi' (2018) 8 Jurnal Politica Dinamika Masalah Politik Dalam Negeri dan Hubungan Internasional.[101].

12 ibid.[102]. 
Muhammad Saad, dkk: The Political Cartel of Presidential...

Table 4. The Strength of the Governing Party in the DPR 2014 Election Results and the Position of Ministers in the Jokowi-JK Working Cabinet

\begin{tabular}{lcc}
\hline SUPPORTING PARTY & $\begin{array}{c}\text { SEATS } \\
\text { IN DPR }\end{array}$ & MINISTER IN CABINET \\
\hline PDIP & 109 & 5 \\
Partai Nasdem & 35 & 3 \\
\hline PKB & 47 & 4 \\
\hline Partai Hanura & 16 & 1 \\
PPP & 39 & 1 \\
PAN & 49 & 1 \\
Partai Golkar & 91 & 1 \\
PKPI & 0 & 1 \\
\hline JUMLAH & $\mathbf{3 8 6}$ & $\mathbf{1 6}$ \\
\hline
\end{tabular}

The coalition was formed in the electoral arena with the main orientation being to win the election. political parties form a coalition and agree to cooperate voluntarily because of the closeness of the party's ideology or program. One form of party coalition is to conduct joint campaign activities to get the most votes in elections. But there are also coalitions formed only to meet the presidential nomination threshold as regulated in the Election Law. This allows political parties with $20 \%$ of seats to nominate themselves without having to form a coalition with other political parties. If not, then they are required to form a coalition with other political parties to achieve a minimum support amount of $20 \%$ of the DPR seats, so it is not surprising that the coalition of political parties is only used as a formality, not because it has the same goal for the progress of the nation.

The coalition of political parties is believed to be a place to conduct political transactions related to their respective interests. Political transactions carried out by means of bargaining for a certain power or position. This is corroborated by several data which state that the political parties in the coalition occupy strategic positions so that this is the reason that the formation of party coalitions only benefits certain groups. 


\section{Conclusion}

The Parliamentary threshold is the basis for the presidential nomination threshold. if we look at the requirements for presidential nomination, those who fall into the category of political parties are those within the parliamentary threshold. Not only that, political parties are still going through the verification stage by the KPU to be designated as political parties participating in the election. Political parties that pass the verification do not have the same rights in submitting presidential candidates in the general election, so the threshold model needs to be reviewed. With the stipulation of a political party as a political party participating in the general election by the KPU, it is deemed to have fulfilled the requirements in the nomination of a presidential candidate. Provisions related to the threshold are considered not only to produce a single candidate because of the formation of party coalitions that accumulate in one large and influential party but also to eliminate the rights of minority political parties in submitting presidential candidates and create political transactions that are influenced by high political costs. KPU is an election management body, if the KPU's job is to accommodate presidential candidates directly from the people and assign them to political parties, then it will not only minimize the occurrence of political cartels and low election costs, but also provide direct choices to the people as well as other alternatives in bringing up candidates. idealistic presidential candidate who will run in the upcoming election. One form of our democracy is holding direct elections by the people. It is the people who have the highest sovereignty in determining who deserves to be promoted as a presidential candidate by political parties, not merely the will of political parties as regulated in the law.

\section{Bibliography}

\section{Books}

Gaffar JM, Demokrasi dan Pemilu di Indonesia (Konstitusi Press 2013).

Isra S, Sistem Pemerintahan Indonesia (Rajawali 2019). 
Muhammad Saad, dkk: The Political Cartel of Presidential...

Reynolds A dan Et.al, Electoral System Design : The New InternationalIDEA Handbook (International IDEA 2015).

Streb MJ, Law and Elections Politics: The Rules of the Game (Routledge 2013).

\section{Journals}

Ristawati R, 'Pemilihan Umum Presiden dan Wakil Presiden Indonesia dalam Kerangka Sistem Pemerintahan Presidensiil’ (2009) 2 Jurnal Konstitusi.

Romli L, 'Koalisi dan Konflik Internal Partai Politik pada Era Reformasi' (2018) 8 Jurnal Politica Dinamika Masalah Politik Dalam Negeri dan Hubungan Internasional.

Rumesten I, 'Fenomena Calon Tunggal dalam Pesta Demokrasi' (2016) 13 Jurnal Konstitusi.

Suharizal, 'Legalitas dan Implikasi Calon Tunggal pada Pemilu Presiden 2009' (2009) 2 Jurnal Konstitusi.

Wiratraman HP, 'Pemilu dan Neo-Otoritarianisme', Prosiding Konferensi Hukum Tata Negara (2019).

\section{Articles}

Asshiddiqie J, 'Memperkuat Sistem Pemerintahan Presidensiil' Pidato Ilmiah Universitas Negeri Jember (14 November 2001).

Badan Pengembangan dan Pembinaan Bahasa, Kementerian Pendidikan, Kebudayaan, Riset dan Teknologi Republik Indonesia, "KBBI Daring" (2016) <https://kbbi.kemdikbud.go.id/entri/AMBANG BATAS> diakses 28 September 2021.

\section{Regulations}

Undang-Undang Nomor 12 Tahun 2003 Tentang Pemilihan Umum Anggota Dewan Perwakilan Rakyat, Dewan Perwakilan Daerah, dan Dewan Perwakilan Rakyat Daerah (Lembaran Negaara Republik Indonesia Tahun 2003 Nomor 37, Tambahan Lembaran Negara Republik Indonesia Nomor 4277).

Undang-Undang Nomor 23 Tahun 2003 Tentang Pemilihan umum Presiden dan Wakil Presiden (Lembaran Negara Republik Indonesia Tahun 2003 Nomor 93, Tambahan Lembaran Negara Republik Indonesia Nomor 4311).

Undang Undang Nomor 42 Tahun 2008 Tentang Pemilihan umum Presiden dan 
Wakil Presiden (Lembaran Negara Republik Indonesia Tahun 2008 Nomor 176, Tambahan Lembaran Negara Republik Indonesia Nomor 4924).

Universal Declaration of Human Rights, The Declaration was proclaimed by the United Nations General Assembly in Paris on 10 December 1948 (General Assembly resolution 217 A).

Declaration on Criteria for Free and Fair Elections, Unanimously adopted by the Inter-Parliamentary Council at its 154th session (Paris, 26 March 1994).

International Covenant on Civil and Political Rights, Adopted and opened for signature, ratification and accession by General Assembly resolution 2200A (XXI) of 16 December1966, entry into force 23 March 1976.

Undang-Undang Nomor 8 Tahun 2012, Tentang Pemilihan Umum Anggota Dewan Perwakilan Rakyat, Dewan Perwakilan Daerah dan Dewan Perwakakilan Rakyat Daerah. (Lembaran Negara Republik Indonesia Tahun 2012 Nomor 117. Tambahan Lembaran Negara Republik Indonesia Nomor 5316).

Undang-Undang Nomor 7 Tahun 2017 Tentang Pemilihan umum Presiden dan Wakil Presiden (Lembaran Negara Republik Indonesia Tahun 2017 Nomor 182, Tambahan Lembaran Negara Republik Indonesia Nomor 6109).

How to cite: Muhammad Saad, Dian Fitri Sabrina, Sukardi, 'The Political Cartel of Presidential Candidacy through Threshold Brings Up a Single Candidate' (2022) Vol. 5 No. 1 Media Iuris. 
--This page is intentionally left blank-- 